DIGITALCOMMONS

@WAYNESTATE-
Michigan Journal of Counseling:

Research, Theory and Practice

Volume 37 | Issue 1

Article 3

$3-1-2010$

\title{
Spiritual and Religious Considerations of Michigan Counseling Association Members
}

Jennifer M. Langeland

Western Michigan University

Mary L. Anderson

Western Michigan University

Gary H. Bischof

Western Michigan University

Bradley Will

Follow this and additional works at: https://digitalcommons.wayne.edu/mijoc

\section{Recommended Citation}

Langeland, J. M., Anderson, M. L., Bischof, G. H., \& Will, B. (2010). Spiritual and Religious Considerations of Michigan Counseling Association Members, Michigan Journal of Counseling, 37(1), 16-24. doi:10.22237/mijoc/1267401720

This Article is brought to you for free and open access by the Open Access Journals at DigitalCommons@WayneState. It has been accepted for inclusion in Michigan Journal of Counseling: Research, Theory and Practice by an authorized editor of DigitalCommons@WayneState. 
Spiritual and Religious Considerations of

\section{Michigan Counseling Association Members}

\author{
Jennifer M. Langeland, M.S. \\ Mary L.Anderson, Ph.D. \\ Gary H. Bischof, Ph.D. \\ Western Michigan University \\ Bradley Will, M.A. \\ Private Practice
}

Author Note

Ms. Langeland (Faculty Specialist in Holistic Health and Doctoral Student in Counselor Education) and Drs. Anderson (Assistant Professor and Coordinator of School Counseling) and Bischof (Associate Professor and Coordinator of Marriage, Couple and Family Counseling) are affiliated with the Department of Counselor Education and Counseling Psychology at Western Michigan University. Mr. Will is in private practice.

This study investigated Michigan Counseling Association members' perceptions of spirituality and religion in the therapeutic process. Specifically, this study sought to find out if spirituality and religion were important in the lives of counselors; how they define these concepts; if they have received training in working with these issues in counseling; and if they perceive clients as coming to counseling with spiritual or religious issues. This study confirmed that overall, Michigan counselors consider themselves religious and/or spiritual. Counselors generally did not perceive their clients as coming to counseling with spiritual or religious issues. The majority of counselors reported they did not receive training in these areas.

Keywords: spirituality, religion, counselors, counseling
As counselors, avenues for explicitly exploring the role of spirituality in our own lives and in the lives of our clients have been wrought with uncertainty, mired by potential threats to personal freedoms, and filled with ethical dilemmas. Counselors, more and more are finding the need to navigate this interplay of secular life and spiritual life as clients wrestle with how to overcome obstacles, delusions and suffering (Burke, Hackney, Hudson, \& Miranti, 1999). However, in the United States, the separation of church and state has been woven into the fabric of daily life. In an effort to ensure religious freedom, our founders separated religious or spiritual endeavors from the practices of government and education.

This split has created an implicit distinction in the American psyche, in that matters of religion or spirituality are of a personal nature and carry with them inherent bias and morals. While the usefulness and ethical importance of separating these domains is clear, the current resurgence of professional discussion on these topics suggests that religion and spirituality are not so cleanly addressed in artificial isolation (Burke et al., 1999; Burke \& Miranti, 2001; Hickson, Housley, \& Wages, 2000; Kelly, 1995; Miller, 1999). It is important to note this larger social discourse which separates religion and spirituality from public life. This principle, on which our country was founded, can inform our understanding of the relationship between spirituality and religion in the therapeutic process.

\section{Spirituality and Religion}

In order to provide an adequate discussion of the literature looking at the role of spirituality and religion in the lives of counselors, it is important to consider a confluence in the language used to describe these constructs. First, we will look at the ways in which the constructs have been defined by the counseling field and then how the concept of values has been used in conjunction with these terms.

There is a wide variety of literature attempting to discern the distinction between religion and spirituality; however, there has been no clear agreement in defining these interrelated concepts that are often used as interchangeable in the literature (Maher \& Hunt, 1993). Counseling and psychology literature has attempted to define them as distinct constructs with overlapping meanings. Kelly (1995) states that "religion and spirituality have overlapping meanings insofar as they 
both point to a transcendent, meta-empirical dimension of reality" (p. xiv). He goes on to say that "spirituality generally signifies an affirmation of and participation in the in-depth, transcendent, holistically connected, and inherently meaningful dimension of reality” (p. xiv). Religion on the other hand "embraces spirituality, but also generally signifies specific modes and systems of belief, imaging, and practice that are often institutionalized in creeds, rituals and moral codes” (p. xiv). Burke \& Miranti (2001) echo these definitions stating that spirituality is more of an internal and private experience that emphasizes purpose and meaning, while religious expressions take place in a public space and are situated within institutions. Spirituality is also described as being the unifying dimension of a person's life. That is, spirituality is an important component of health which integrates and gives meaning to the physical, emotional, intellectual and social needs of the person (Fuller, Brown, \& Mills, 2006). While diverse definitions abound, an underlying commonality of both spirituality and religion has been described as a search for meaning and the sacred (Hill \& Pargament, 2003). While definitions of these terms continue to evolve, however it is not clear how counselors define these terms in relation to their personal and professional lives.

Onepotentialproblemwithusingstandard definitions of these constructs is that those counselors claiming religiousness may not see religion and spirituality as distinct (Richards \& Bergin, 1997), while others may feel aligned with the concept of spirituality and reject institutionally based forms of religious belief (Kelly, 1994). This would be an important caveat to research on the role of these concepts in the therapeutic process. If counselors are religious, they may not see these constructs as separate, which would have an impact on how they view these concepts in the therapeutic process. Likewise, counselors identifying themselves as spiritual and rejecting organized religion may have quite different views on the influence of spirituality on the therapeutic process. It is clear that understanding the personal ways in which counselors define these terms would be an important aspect of future research regarding the role of these constructs in the therapeutic process.

\section{Values and Counseling}

What constitutes a person's religious or spiritual beliefs can also be understood using the language of personal values (Grimm, 1994; Kelly, 1994; Patterson,
1989). However, the connection between discussions of counselor values and spiritual and religious beliefs has rarely been made explicit. When one looks more closely at the definition of values it becomes evident that there is an intersection between counselor values and spirituality and religion.

Grimm (1994) defines values as the "complex, comprehensive system by which a therapist makes value judgments in relation to his or her context" (p. 155). Looking at Burke \& Miranti’s (2001) definition of spirituality, “spirituality includes one's capacity for creativity, growth, and the development of a value system” (p. 602), one sees the confluence of personal values and the concept of spirituality. Kelly (1995) in his national survey of counselor values also highlights the connection between values and religion and spirituality by including questions on spiritual and religious values in his survey. Likewise previous studies have revealed that counselors claim to have spiritual and or religious dimensions of their values (Bergin, 1991; Bergin \& Jensen, 1990; Shafranske \& Malony 1990). The Association for Spiritual, Ethical and Religious Values in Counseling (ASERVIC) established competencies for addressing spiritual and religious issues in counseling (Miller, 1999). These core competencies include a counselor's capacity for development of a value system. Although this connection is rarely made explicit in the literature, the concept of values may converge and overlap with a person's definition of spirituality and counseling. This again points to a need for more research to consider the ways in which counselors define these terms. Having considered the complexity inherent in defining these terms, we will consider the many ways these concepts enter the profession of counseling.

\section{Counseling Literature on Spirituality, Religion and Values}

The counseling literature in the last two decades has seen a steady rise in articles, books and chapters looking at the place that religion and spirituality play in the therapeutic process (Burke \& Miranti, 2001; Hall, Dixon, \& Mauzey, 2004; Cashwell \& Young, 2005; Gold, 2010; Kelly 1995; Miller, 1999; Powers, 2005; Richards \& Bergin, 1997; Young, Cashwell, WigginsFrame, \& Belaire, 2002). Traditionally, counseling theorists have separated the counselor's values from the therapeutic process, based on the belief that counselors might unconsciously impose their values and beliefs on their clients (Hagedorn, 2005). Consequently, 
counselors have been directed not to allow their values to influence the therapeutic process (Grimm, 1994). Ethics textbooks have advised trainees to avoid imposing their values on their clients (Corey, Corey, \& Callanan, 2007) and the governing body of the counseling profession, the American Counseling Association (ACA, 2006) has implied in its code of ethics that personal values and beliefs should not enter the therapeutic process. Meanwhile, members of the counseling profession, sensing the importance of these concepts in the lives of their clients held a summit on spirituality and religion in 1995 and outlined core competencies that counselors must have in order to meet the spiritual and religious needs of their clients (ACA, 1995).

There have been two distinct ways in which the profession has begun to address the role of spirituality and religion in the therapeutic process. The first has been with an eye toward the spiritual and religious life of the client; the second has been with an eye toward the spiritual and religious life of the counselor.

Clients' spirituality and religion. The literature considering the role of spirituality and religion in clients' lives has emphasized two areas: (1) Understanding the variety of religious or spiritual beliefs that a client might bring to counseling and how to educate / train counselors on the ideas, rituals and practices that inform those belief systems and, (2) Understanding the mental health benefits of religion and spirituality. This line of thinking, which considers the religiousness or spirituality of the client, focuses on improving the multicultural competencies of the counselor and therapeutic outcomes (Burke \& Miranti, 2001). In response to the need to address counselor competency in this area, the ASERVIC competencies (Miller, 1999) noted above detailed nine core competencies for integrating spirituality and religious issues into counseling. These competencies included counselor self-awareness, knowledge and acceptance of diverse religious and spiritual beliefs, and the ability to assess and employ clients' religious and/or spiritual beliefs in the pursuit of therapeutic goals. These original competencies were recently revised and expanded to include fifteen (ASERVIC, 2009). A new area included in the updated competencies is culture and worldview, which reflects a focus on diversity in the profession that supports the exploration of the various cultural influences in a client's life, including their spiritual or religious beliefs and how these inform choices, behaviors, and ideas about change (Bishop, 1995;
Fukuyama, Siahpoush, \& Sevig, 2005; Wiggins-Frame, 2003).

Additionally, this body of literature has begun to consider the therapeutic benefits of incorporating a client's religious or spiritual beliefs into the therapeutic process (Burke \& Miranti 2001; Gold, 2010; Helmeke \& Bischof, 2002). Recognition of the potentially powerful nature of a client's religious or spiritual beliefs and how when incorporated into counseling may readily facilitate change is a potent line of research (Young et al., 2002). In fact, Kelly (1995) in his book titled Spirituality and Religion in Counseling and Psychotherapy: Diversity in Theory and Practice summarized a Gallup poll, which suggests that when faced with a serious problem, the majority of people would prefer to see a counselor who holds spiritual values or beliefs.

Counselors' spirituality and religion. The second major approach to the role of religion and spirituality in the therapeutic process has an eye toward the counselor. Considering the role of religion and spirituality in the lives of counselors has received less attention in the literature despite the fact that there is potential influence (Hall et al., 2004). Gallup Polls have been collecting information on the spiritual and religious lives of Americans for decades and a recent report by the Gallup Poll organization stated that across these years of study, approximately 9 in 10 Americans believe in God, a higher power or universal spirit (Winseman, 2005). This suggests that Americans, in large numbers, struggle with, claim, practice, or have some engagement with religion or spirituality.

Given the widespread acknowledgement of spiritual or religious beliefs in the general public it is likely that many counselors claim such beliefs as well (Kelly, 1995). In fact, in a national study of the spiritual and religious value orientations of mental health professionals it was found that most mental health professionals have spiritual and religious values (as cited in Grimm, 1994). Although it is crucial for counselors to honor issues of diversity within the counseling relationship, there is limited research considering the counselors' perspective of the role of spirituality and religion in the therapeutic process (Hickson et al., 2000).

As a profession, understanding how spirituality and religion might inform and shape counselors' values and how they might influence the therapeutic process is only ethical given the likelihood that counselor values interact with the therapeutic process (Hall et al., 2004). 
In fact, Corey et al. (2007) state that counselors will inevitably incorporate certain value orientations in their approaches and methods. Therefore, the nature of the relationship between counselors' perceptions of spirituality and religion and the therapeutic process may be important to our professional understanding of what role these concepts play in the counselors' choice of theory, practical application of theory, and as a protective factor against burnout.

Similarly, while there have been many efforts in the literature to define spirituality and religion, little attention has been given to the ways in which counselors define these terms. If we can understand the ways in which counselors define these concepts, the profession could better understand their influence in counselors' lives and on the therapeutic process. Importantly, understanding counselors' perceptions of these concepts could give insight into the ways in which they influence the therapeutic process which otherwise may be held in implicit abeyance, having an unacknowledged influence on the process. Although spirituality is basic to the human experience, most counselors do not receive comprehensive training in this area, and may avoid addressing spiritual and/or religious issues with clients for this reason (Weinstein, Parker, \& Archer, 2002).

\section{Statement of the Problem}

The literature reviewed above suggests an interesting problem. We have seen that counselors are likely to consider themselves religious or spiritual. We do not know if counselors draw upon their own spiritual or religious resources when counseling others, if they are receiving adequate training to deal with these issues, and how they define these concepts. Given the fact that the general population as well as counselors report a belief in God, or spiritual or religious beliefs that are important in their lives, the following study was proposed to explore counselors' perceptions of spirituality and religion in the therapeutic process.

\section{Methods}

\section{Research Questions}

The following research questions were considered:

1. Do counselors consider religion or spirituality an important part of their life?

2. Do counselors believe they have received adequate training to deal with spiritual or religious issues that a client might bring to counseling?

3. What concepts do counselors use to define religion or spirituality?

4. Do counselors perceive clients as coming to counseling with religious or spiritual issues?

\section{Population and Sample}

From the Michigan Counseling Association headquarters, a database of names and addresses of all members $(n=1725)$ was obtained. From this database a random sample of 350 were selected. Each of the 350 participants received: (1) a cover letter requesting his or her voluntary participation in the study; (2) two copies of the consent form (one to be signed and returned, the other to be retained by the participant); (3) a stamped return envelope; (4) and the survey. The total number of surveys returned was 206 (67\% response). Due to the high response rate, no follow up requests were mailed and no alternates were used. For this study, no analysis of participant bias was conducted, but it could be that those responding to the survey are more likely to have an interest in spiritual and religious issues. The total of 206 respondents yields a +/- confidence interval of $6.4 \%$ at the $95 \%$ confidence level, slightly higher than standard desired $4.5 \%$ confidence interval.

The study sample included practitioners who held a variety of degrees; $81 \%$ held a master's, $12 \%$ held doctorates and $6 \%$ were students. Additionally, the respondents consisted of $53 \%$ in school counseling, $25 \%$ rehabilitation counselors, $16 \%$ in private practice, $4 \%$ in counselor education, and $1 \%$ were students. The majority of the sample was seeing 16 or more clients per week. The gender of the population was relatively consistent with the American Counseling Association's national statistics (female $=78 \%$; male $=22 \%$ ).

\section{Survey Instrument}

The construction of a survey for this study took place in several steps. Because the purpose of the study was to inquire about spirituality and religion in the personal and professional lives of counselors, the authors looked at a variety of instruments which assessed spirituality and religiousness. A Michigan-based foundation published a compilation of instruments assessing spirituality and religiousness along with a variety of subscales (Fetzer Institute, October 1999). Survey questions from that document were evaluated for their relevance with regards to this study. While no direct 
portion of these scales was utilized, questions from this instrument were used as a guide. Finally, the constructed survey was reviewed by three other individuals for face validity. One of the reviewers had expertise in the field of counseling, one had expertise in statistics and survey construction, and one individual had expertise in the area of religion and spirituality. Changes were made to the survey after these reviews.

In the first portion of the survey, participants were asked to respond to a series of demographic questions including gender, field of counseling, number of years counseling, level of education, how many clients seen per week, and age. The second portion of the survey consisted of 11 questions, seven of which were Likerttype questions, 3 of which were check all that apply-type questions, and one question which was an open ended question. The Likert-type questions asked participants to indicate how important religion and spirituality were in their daily life on a scale from 1 (not at all) to 5 (very much so). In this section, participants were also asked to respond to two Likert-type questions regarding training issues; did your professional training address issues of spirituality and religion from 1 (not at all) to 5 (very much so).

Participants were also asked if they perceived religion and spirituality as separate constructs with 1 indicating (not at all) and 5 indicating (very much so). The purpose of this question was to assess the degree to which these constructs are perceived as separate or distinct constructs. Finally, participants were asked to respond to two separate Likert-type questions regarding how often clients come into counseling with issues related to their religion or spirituality with 1 indicating "not at all” and 5 indicating "very often.” In the "check all that apply" portion of the survey participants were asked to check the words of statements that they believed to be important aspects of spirituality. Examples of these words include: connection to something larger than self, tranquility, concern for others, forgiveness, and meaning making.

\section{Results \\ To determine whether or not counselors perceive themselves as religious or spiritual, question 7: How important is religion in your daily life and question 9: How important is spirituality in your daily life were evaluated using frequency tabulations - and percentages. The results to these two questions are presented in Table 1. Most counselors reported that religion is important (sum of the responses 3-5 in the likert scale) in their daily life $(70 \% ; n=144)$. Additionally, counselors reported at even greater rates that spirituality is important in their daily life $(95 \% ; n=189)$.}

When respondents were asked if they perceive clients as coming to counseling with religious or spiritual issues, only 34\% of respondents reported that clients come to counseling with issues related to their religion $(n=70)$. A moderate number reported that clients come with issues regarding spirituality (56\%, $n=115$ ).

When respondents were asked if their professional training addressed issues of spirituality, only 21\% reported that they received training in this area $(n=43)$. In order to better understand how counselors define the term spirituality two questions were asked: "Do you perceive religion and spirituality as separate constructs?" and "Which concepts (of a list of eleven terms) are the most important aspects of spirituality?" Approximately four out of five counselors reported that they perceive religion and spirituality to be separate constructs (79\%, n=163). Respondents were asked to indicate which terms or phrases they considered to be the most important aspects of spirituality. The results, given as percentage of respondents who checked term or

\section{TABLE 1}

\section{Counselors' Ratings of Importance of Religion and Spirituality}

Response (\%)

12

(Not at all)
3

$14 \quad 16$

23
18

14
4

(Very much so)

Questions:

$\begin{array}{lcrrrr}\text { 1. How important is religion in your daily life? } & 14 & 16 & 18 & 23 & 29 \\ \text { 2. How important is spirituality in your daily life? } & 2 & 3 & 14 & 26 & 55\end{array}$


phrase as important, are as follows (only the top five are listed here, see Table 2 for complete results): connection to something larger than self $(87 \%, n=179)$; tranquility, peace and joyful living $(70 \%, n=144)$; acceptance of self and others $(70 \%, n=144)$; searching $(62 \%, n=128)$; inner directed $(61 \%, \mathrm{n}=126)$.

\section{Discussion}

This research supports previous research indicating that counselors perceive themselves to be more spiritual than religious. The percentages reported here on the religiousness of counselors are lower then those reported in the national survey done by Kelly in 1995. The results from this study are generalizable to counselors in the state of Michigan and may have some relationship to counselors in the Midwest. However, comparisons to other regions in the country could yield interesting regional or cultural distinctions with regards to this issue.

Counselors in this study reported that they did not believe that they received adequate training in religious and spiritual issues. In fact only $21 \%$ felt that these issues had been addressed in their training program. When this data is compared with the study done by Young et al. (2002), which found that 69\% of
CACREP accredited programs said that they addressed spiritual and religious issues in training, an interesting inconsistency emerges. It may be that many programs address religion and spirituality in an elective or as part of a course on multiculturalism. Although the sample from this study is not nationally generalizable, the results suggest that there may be a gap between what training programs perceive themselves as offering and counselors' perception of that training. It may also be that when the respondents of this study went through their graduate training little attention was paid to matters of spirituality and religion and that this has increased over time.

This study suggests that counselors consider themselves more spiritual than religious; however a large number of the respondents reported religion also to be important in their daily lives. Future research should consider the different ways in which counselors who consider themselves only spiritual, counselors who consider themselves only religious, and counselors who consider themselves both religious and spiritual, perceive religion and spirituality in the therapeutic process. Results from these types of inquiries could yield fruitful information about the influence of these constructs on counselors' lives and the therapeutic

TABLE 2

\section{Counselor's Perception of Important Aspects of Spirituality}

Item and Ranking

1. Connection to something larger than self

2. Tranquility, peace, joyful living

3. Acceptance of self and others

4. Searching

5. Inner directed

6. Forgiveness

7. Concern for others, service

8. Meaning making

9. Acceptance of death

10. Happiness

11. Acceptance of suffering, fear, pain n

179

144

144

128

126

120

115

99

80

74

68
$\%$

95\%CI*

(81-93\%)

(64-76\%)

(64-76\%)

(56-68\%)

(55-67\%)

(52-64\%)

(50-62\%)

(42-54\%)

(33-45\%)

(30-42\%)

(27-39\%)

*95\% Confidence Interval based upon +/- 6.4\% based upon sample size and response rate, rounded here to +/- 6.0. 
process.

Another important consideration is how counselors define these constructs of spirituality or religiousness. The results from this study are limited by the structure of the questioning. However, this investigation begins to illuminate some of the constructs that underlie counselors' definition of spirituality. Future research should consider qualitative methods to uncover the deep meaning undergirding both concepts and how counselors integrate these into their clinical practice. It is interesting to note that counselors in this study chose five primary constructs as being central to their definition of spirituality including: connection something larger, tranquility, peace, joyful living, acceptance of self and others, and being inner directed. These constructs suggest that counselors have certain values that are the core of their spirituality. This question is limited by the structure of the question ("check all that apply" type). Other dimensions not included on the list might also be important. Future research should again consider a qualitative approach or use of open-ended questions to further refine counselors' considerations of these concepts.
As Kelly (1995) noted, it is likely that the secular settings in which most counselors work, in keeping with the cultural norm to keep spiritual and religious concerns private, passively encourage a neutral stance or avoidance with regards to client spirituality and religiousness. The quantitative results of this survey support this statement, although additional research is necessary to determine if the socio-cultural bifurcation is influencing counselors' neutral stance or avoidance of these issues in the therapeutic milieu.

A large majority of respondents in this survey work in school settings (53\%, $n=109$ ), most in public schools. The fact that many respondents reported that clients are not bringing spiritual or religious issue to counseling may be a result of the developmental level of the clients of school counselors. Another important factor that may have skewed this data is that many public schools have restrictions on the discussion of religious or spiritual material in the school. Public schools have been one highly contentious arena where the public debate about the separation of church and state has taken place. Thus, future research might compare school counselors in religious-affiliated schools and those in public schools.

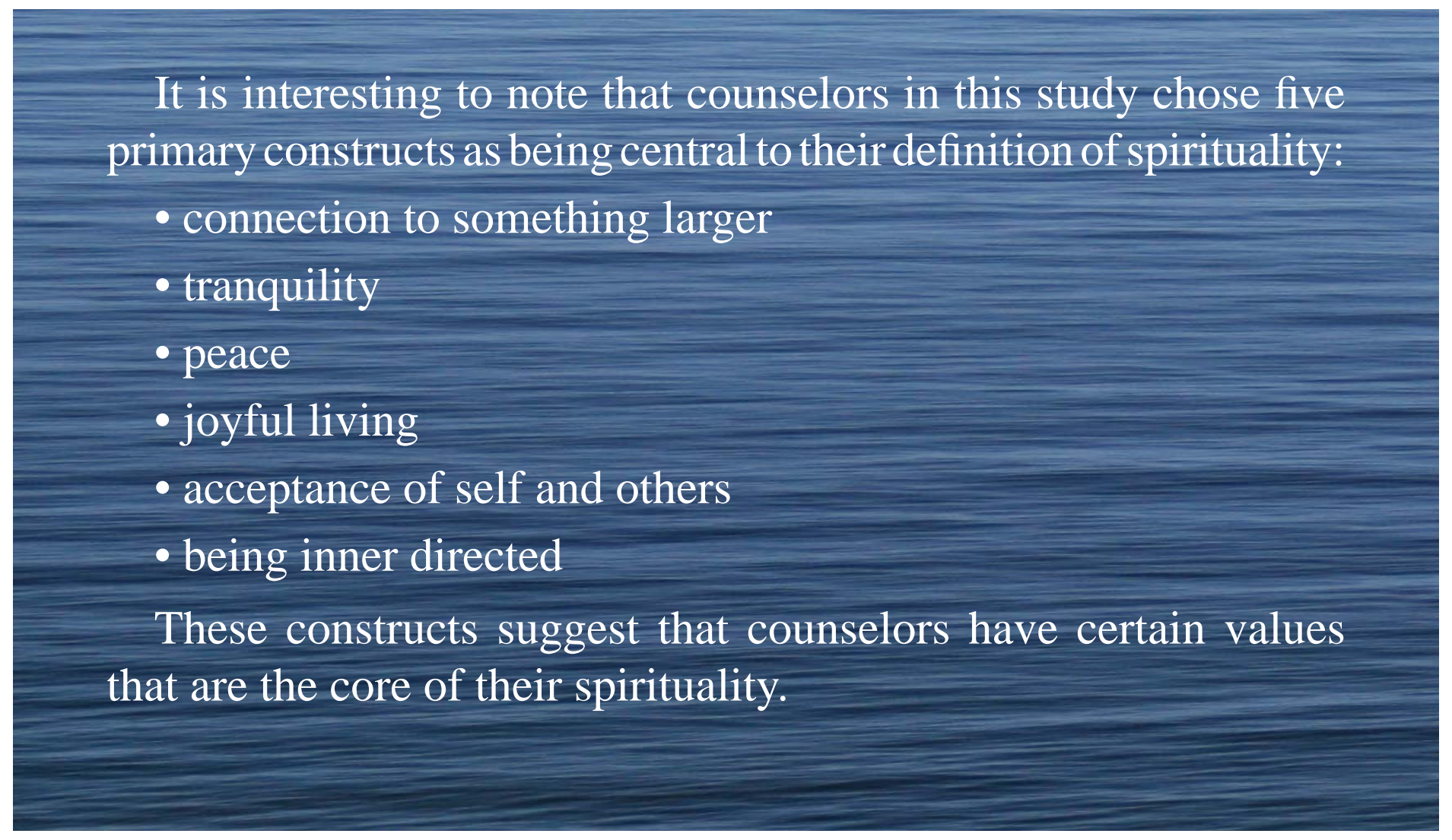




\section{References}

American Counseling Association (1995, December). Summit results in information of spirituality competencies. Counseling Today, 37, 30.

American Counseling Association (2006). Code of ethics. http://www.counseling.org Retrieved: March 23, 2006.

Association for Spiritual, Ethical and Religious Values in Counseling (2009). Competencies for addressing Spiritual and Religious Issues in Counseling. http://www.aservic.org/competencies.html Retrieved: April 27, 2010.

Bergin, A. E. (1991). Values and religious issues in psychotherapy and mental health. American Psychologist, 46, $394-403$.

Bergin, A. E., \& Jensen, J. P. (1990). Religiosity of psychotherapists: A national survey. Psychotherapy, 27, 3-7.

Bishop, D. R. (1995). Religious values as cross-cultural issues in counseling. In M. T. Burke \& J. G. Miranti (Eds.), Counseling: The spiritual dimension (pp. 59-71). Alexandria, VA: American Counseling Association.

Burke, M. T., Hackney, H., Hudson, H., \& Miranti, P. (1999). Spirituality, religion, and CACREP curriculum standards. Journal of Counseling and Development, 77, 251-257.

Burke, M. T., \& Miranti, J. (2001). The spiritual and religious dimensions of counseling. In D. C. Locke, J. E. Meyers, E. L. Herr (Eds.), The handbook of counseling (pp. 601-612). California: Sage Publications.

Cashwell, C. S., \& Young, J. S. (2005) Integrating spirituality and religion into counseling: A guide to competent practice (pp. 85-103). Alexandria, VA: American Counseling Association.

Corey, G., Corey, M. S., \& Callanan, P. (2007). Issues and ethics in the helping professions (7th ed.). Pacific Grove, CA: Brooks/Cole Publishing.

Fetzer Institute/National Institute on Aging Working Group (1999). Multidimensional measurement of religiousness/spirituality for use in health research.

Fukuyama, M. A., Siahpoush, F., \& Sevig, T. D. (2005). Religion and spirituality in a cultural context. In C. S. Cashwell \& J. S. Young (Eds.), Integrating spirituality and religion into counseling: A guide to competent practice (pp. 123-142). Alexandria, VA: American Counseling Association.

Fuller, K., Brown, C., \& Mills, J. (2006). Holism and holistic health. (Available from McGraw-Hill Companies, P.O. Box 182604, Columbus, OH 43272).

Gay, L. R., \& Airasian, P. (2000). Educational research: Competencies for analysis and application (6th ed.). New Jersey: Prentice-Hall.

Gold, J. M. (2010). Counseling and spirituality: Integrating spiritual and clinical orientations. Upper Saddle River, NJ: Merrill.

Grimm, D. W. (1994). Therapist spiritual and religious values in psychotherapy. Counseling and Values, 38, 154-164.

Hagedorn, W. B. (2005). Counselor self-awareness and self-exploration of religious and spiritual beliefs: Know thyself. In C. S. Cashwell \& J. S. Young (Eds.), Integrating spirituality and religion into counseling: A guide to competent practice (pp. 63-84). Alexandria, VA: American Counseling Association.

Hall, C. R., Dixon, W. A., \& Mauzey, E. D. (2004). Spirituality and religion: implications for counselors. Journal of Counseling \& Development, 82, 503-508.

Helmeke, K. B., \& Bischof, G. H. (2002). Recognizing and raising spiritual and religious issues in therapy: Guidelines for the timid. Journal of Family Psychotherapy, 13, 195-214.

Hickson, J., Housley, W., \& Wages, D. (2000). Counselor's perceptions of spirituality in the therapeutic process. Counseling and Values, 45, 58-66.

Hill, P. C., \& Pargament, K. I. (2003). Advances in the conceptualization and measurement of religion and spirituality: Implications for physical and mental health research. American Psychologist, 58, 64-74. 


\section{References}

Kelly, E. W. (1994). The role of religion and spirituality in counselor education: A national survey. Counselor Education and Supervision, 33, 227-237.

Kelly, E. W. (1995). Spirituality and religion in counseling and psychotherapy: Diversity in theory and practice. Alexandria, VA: American Counseling Association.

Maher, M. F., \& Hunt, T. K. (1993). Spirituality reconsidered. Counseling and Values, 38, 21-28.

Miller, G. (1999). The development of a spiritual focus in counseling and counselor education. Journal of Counseling and Development, 77, 498-501.

Patterson, C. H. (1989). Values in counseling and psychotherapy. Counseling and Values, 33, 164-181.

Powers, R. (2005). Counseling and spirituality: A historical review. Counseling and Values 49, 217-225.

Richards, P. S., \& Bergin, A. E. (1997). A spiritual strategy for counseling and psychotherapy. Washington, DC: American Psychological Association.

Shafranske, E. P., \& Malony, H. N. (1990) Clinical psychologists' religious and spiritual orientations and their practice of psychotherapy. Psychotherapy, 27, 72-78.

Weinsten, C. M., Parker, J., \& Archer, J. (2002). College counselor attitudes toward spiritual and religious issues and practices in counseling. Journal of College Counseling, 5, 164-174.

Wiggins Frame, M. (2003). Integrating religion and spirituality into counseling. Pacific Grove, CA: Brooks/Cole.

Winseman, A. L. (2005). Americans have little doubt God exists. Gallup Poll report December 13. http://poll.gallup.com/ content/default.aspx?ci=20437. Retrieved: March 23, 2006.

Young, S. J., Cashwell, C., Wiggins-Frame, M., \& Belaire, C. (2002). Spiritual and religious competencies: A national survey of CACREP-accredited programs. Counseling and Values, 47(1), 22-33. 